\title{
Effect of Seedling Density and Bed Type on Growth of Elm (Ulmus wallichiana) Seedlings in the Nursery
}

\author{
Arshad Hussain Mughal", G.M.Bhat, J.A.Mugloo \\ Faculty of Forestry, SKUAST Kashmir, J\&K, India \\ *Corresponding Author: ahmughal1@rediffmail.com
}

Copyright $@ 2014$ Horizon Research Publishing All rights reserved.

\begin{abstract}
Ulmus wallichiana is an important multipurpose tree species of the Himalayan region suitable for furniture, leaves are consumed as fodder while as small wood is used as fuel wood. Elm seeds are minute and are generally broadcasted in the nursery beds, thereafter they need to be thinned out or transplanted so that they achieve transplantable height. The study aimed at studying the effect of seedling density and bed type on the growth of Ulmus wallichiana seedlings over a period of two years \& was undertaken under All India Coordinated Research Project on Agroforestry at Srinagar centre, India. The seedlings were evaluated in nursery beds, transplant beds and thinned out nursery beds. The study concluded that undisturbed seedling beds with a density of 400 seedlings $/ \mathrm{m}^{2}$ recorded maximum height of $1.51 \mathrm{~m}$ but seedling collar diameter was minimum. Maximum diameter of $9.56 \mathrm{~mm}$ was recorded in undisturbed thinned out nursery beds having a density of only 100 seedlings $/ \mathrm{m}^{2}$ but height recorded was only $1.39 \mathrm{~m}$. Transplant beds recorded a height of $1.19 \mathrm{~m}$ and a diameter of $7.19 \mathrm{~mm}$. In the present study it is evident that the seedlings need not to be necessarily transplanted from seedling beds but in the second year if proper density $\left(100 \mathrm{~m}^{3}\right)$ is maintained by thinning, maximum seedling growth in terms of both height and diameter can be achieved.
\end{abstract}

Keywords Transplant Beds, Seedling Beds, Thinned Out Nursery Beds, Ulmus Wallichiana

\section{Introduction}

Elm belongs to the family Ulmaceae and is distributed in the Himalayas from Kashmir to Uttranchal, India and Nepal within an altitude of $900-3,000 \mathrm{~m}$ [1].The species is also scattered in Central Nuristan (Afghanistan). In India the species is distributed over the states of Jammu and Kashmir, Uttranchal, and Himachal Pradesh. In the state of Jammu and Kashmir distribution of Elm has been reported in all the districts of Kashmir though their concentration varies from district to district [2]. Elm if allowed to grow attains a great height and girth. Leaves of elm are suitable for fodder, bark yields a strong fibre, useful for cordage and for rope making and sandals. Timber is used for making trays, ploughs, building and fuel. The young shoots are much esteemed as fodder for buffaloes. It is also suitable for furniture, light construction and planking $[3,4]$. Due to its multifarious uses the tree has been heavily exploited, as a result of which, the species has become vulnerable [5]. Natural regeneration of the species is very poor due to high incidence of empty seeds, besides seeds of the species are scarcely available and if available are not viable because of their short viability and thus afforestation by artificial means is difficult. Germination of seeds is about $96 \%$ if collected at the proper time well before the seeds lose their viability. Seeds of elm are very minute and weigh about $10.14 \mathrm{~g}$ per 1,000 seeds [6].

Elm in the beginning is very slow growing and after germination need to be transplanted to transplant beds for another year so that they can attain transplantable height. Since, the seeds are small so they cannot be sown at predetermined spacing in the nursery beds and as such broadcasting is the only method of seed sowing in the nursery. Broadcasting of seeds does not maintain the proper density of seedlings in the nursery beds as a result of which germinating seedlings have to compete for space and nutrients for their growth. The seedlings are kept in the nursery beds for at least 2 years till they attain a transplantable height. For the production of premium quality trees the health and quality of seedlings are essential. Nursery raising of plants should aim at vigorous healthy plants of uniform size. Seedling grade or quality is important, but there is no single parameter which adequately assesses quality [7].

Seedlings planted in the forests or on farmland are produced in nurseries. Bare-root seedlings are grown in nursery beds for two to four years, depending on species and size required, and then dispatched for field planting. The stock may remain in the same seedbed throughout the nursery cycle of production (usually about two years), or after one or two years in the seedbed it may be transplanted into another bed at a lower growing density to produce larger stock. Field grown seedlings and transplants are categorised by age. A $2+0$ plant is a seedling that has grown for two years in the same location from seed, while as $1+1$ plant is a 
transplant which has grown for one year in seedling bed and one year in transplant bed[8]. For some species the transplanting process makes the plant more vigorous. Choice of stock type depends on factors such as species, availability, planting method and cost. Whatever the stock type, seedlings should be of the best quality, uniform and healthy.

In order to overcome the problem of slow growth and obtain vigorous and uniform seedlings of Elm in the nursery, an experiment was designed to compare the growth of seedlings in seedling seed beds, transplant beds and thinned out seedling beds so that the technology could be standardized for raising quality seedlings in nursery.

\section{Material and Methods}

The experimental trial was laid at Shalimar, Kashmir situated at Srinagar, India between $32^{\circ} 17$ and $36^{\circ} 58 \mathrm{~N}$ latitude and $72^{\circ} 26$ and $83^{\circ} 20 \mathrm{E}$ longitude at an elevation of $1,584 \mathrm{~m}$ and the climate of the region falls under temperate climatic regimes with mean annual rainfall of $660 \mathrm{~mm}$ and mean temperature of $13.3^{\circ} \mathrm{C}$. Minimum temperature of the area may drop to $-7^{0} \mathrm{C}$ in winter months while as maximum temperature may touch to $35^{\circ} \mathrm{C}$ in summer. Soil at the experimental site is silty clay loam in texture, neutral having available nitrogen of $100 \mathrm{~kg} / \mathrm{ha}$, phosphorus $10 \mathrm{~kg} / \mathrm{ha}$ and potassium $200 \mathrm{~kg} /$ ha with good water holding capacity. Seeds of Elm after collection in the month of April 2009 were broadcasted in the nursery beds of size $1 \mathrm{~m}^{2}$ maintaining a density of about 400 seedlings. After germination and completion of one year growth in the nursery beds an average height of $0.69 \mathrm{~m}$ and collar diameter of $3.98 \mathrm{~mm}$ was attained. After the first growing season in the nursery, plants were trained to a single leader, and lateral branches pruned off $5 \mathrm{~cm}$ of the main stem. Thereafter for the next year, 2010 three treatments were designed for evaluation and laid in randomised block design. All the treatments were replicated 20 times. In one of the treatments $\left(\mathrm{T}_{1}\right)$ earlier density of 400 seedlings/ $\mathrm{m}^{2}$ of nursery beds was maintained while as in other $\left(\mathrm{T}_{2}\right)$ some seedlings were removed and density of 100 seedlings $/ \mathrm{m}^{2}$ was maintained with a spacing of $10 \times 10 \mathrm{~cm}$. In treatment $\mathrm{T}_{3}$ the seedlings after being removed from nursery beds were transplanted in transplant beds at a spacing of $10 \times 10 \mathrm{~cm}$ and as such density of 100 seedlings $/ \mathrm{m}^{2}$ was maintained. Seedlings were thinned and transplanted in dormant winter season (December 2009). During the evaluation period (January to December 2010) the seedling beds were regularly watered and weeded and hoeing was also carried out as and when required. The seedlings were evaluated at the end of the growing season in terms of height, collar diameter and biomass. From each plot, five plants nearest the mean stem diameter and height were selected for aboveground biomass measurements. Data was statistically analyzed using Minitab programme.

\section{Results}

Table depicting data shows the effect of different treatments on the height, collar diameter and biomass of elm seedlings. Bed density significantly affected diameter, height and biomass of seedlings. Differences among various treatments were statistically significant at 5\% level of significance. Seedlings kept in nursery beds without transplanting and having a density of 400 seedlings in the nursery beds recorded an average height of $1.51 \mathrm{~m}$ which was more than the height recorded in thinned out nursery beds $(1.39 \mathrm{~m})$ and transplant beds $(1.19 \mathrm{~m})$. Recorded height in seedlings beds was $8.63 \%$ and $26 \%$ more than thinned out and transplant beds respectively.

Regarding collar diameter it was maximum of $9.56 \mathrm{~mm}$ in thinned out nursery beds with a standard deviation of 0.17 , followed by 7.19 in transplant beds and $5.37 \mathrm{~mm}$ in seedling nursery beds. Collar diameter recorded in thinned out nursery beds was $78 \%$ more than seedling beds and $33 \%$ more than transplant beds. Biomass followed the same trend as that of collar diameter. Maximum biomass significant at $5 \%$ level was recorded in thinned out seedling beds $(55 \mathrm{~g})$ followed by transplant beds (44g). Seedling nursery beds recorded a biomass of only $38 \mathrm{~g}$.

\section{Discussion}

The easiest method to asses quality of seedling is to measure height and stem diameter, which are often well-correlated with later growth in the field $[9 ; 10]$.

Table 1. Growth of Ulmus wallichiana seedlings in the nursery as affected by density in seedling and transplant beds

\begin{tabular}{|c|c|c|c|c|c|}
\hline & Treatment & Density $/ \mathbf{m}^{2}$ & Height(m) & Collar diameter (mm) & Biomass (g) \\
\hline 1 & Seedling nursery bed & 400 & 1.51 & 5.37 & 38 \\
\hline 2 & Thinned nursery bed & 100 & 1.39 & 9.56 & 55 \\
\hline 3 & Transplanted nursery bed & 100 & 1.19 & 7.19 & 44 \\
\hline & Mean & & 1.36 & 7.37 & 45.66 \\
\hline & St. deviation & & 0.04 & 0.17 & 10 \\
\hline & Critical Difference at 5\% & & 0.02 & 0.11 & 5.22 \\
\hline
\end{tabular}


Maximum height was recorded in seedling beds because the seedlings were not disturbed besides, when density of seedlings is more the seedlings tend to become tall and thin. Smith reported that results in the nursery confirm the principle that height growth is relatively constant over a wide range of stand densities [11]. Many factors affect the performance of plants in seedbeds, transplant beds and the field. Nursery bed density and seedling grade besides mineral nutrition are two of the most important. In general, average plant size increases as bed density decreases [10], and the percent yield of usable seedlings is frequently higher at lower bed densities [12]. Maximum diameter in thinned out nursery bed is due to the fact that the seedlings were not disturbed during the second year but were given ample space for growth by removing excess of seedlings from the nursery beds through thinning. Seedling nursery beds had a density of 400 seedlings and so cannot compete with thinned or transplanted nursery beds. Seedlings once removed from seedling beds receive shock and on transplantation in transplant beds have to overcome the shock and as such cannot compete with already established seedlings in seedling beds so it is perhaps the reason that seedlings did not get a thicker collar diameter. Transplanting process generally results in a large calliper and a more fibrous root system. The seedlings will have more side branching. The root system on a $1+1$ plus the extra storage of food in the calliper and root system will allow the seedling to survive on an infertile sites, compete with other vegetation and give it a better chance of surviving browse damage. On the other hand seedlings kept in beds for 2 years without being transplanted are ready of planting out, production cost is low because seedling has not been transplanted. This stock type will survive in a site that has low competing vegetation and minimum levels of animal browsing.

\section{Conclusions}

Nursery technology for raising seedlings in seedling beds, transplant beds and thinned out beds also play an important role as has been clearly demonstrated by the present investigation. Thus, selection of optimum bed density (density which produces the maximum number of usable seedlings per unit area) and type of nursery bed (Transplant, thinned out and seedling bed) assumes importance for raising suitable nursery crop. In the present study it is evident that the seedlings need not to be necessarily transplanted from seedling beds but in the second year if proper density (100 $\mathrm{m}^{3}$ ) is maintained by thinning, maximum seedling growth in terms of both height and diameter can be achieved. Transplanting on the other hand may result in fibrous root system but growth cannot be comparable with seedlings in undisturbed beds because they have to overcome the shock of transplantation which needs time.

\section{Acknowledgements}

Authors are highly thankful to National Research Centre for Agroforesry, Jhansi India for providing the necessary funds under AICRP-AF for conduct of the said research. Authors are also thankful to the authorities of Sher e Kashmir University of Agricultural Sciences and Technology Kashmir, India for providing necessary facilities for smooth conduct of the research programme.

\section{REFERENCES}

[1] Troup, R.S. (1921). Silviculture of Indian Trees, Clarendon press, London

[2] Bhat, G.M, Khan,M.A and Mughal,A.H (2007a).Status distribution and concentration of Elm (Ulmus wallichiana) A Multipurpose Tree species in Kashmir. SKUAST, J. Research 9;84-88.

[3] Gamble, J.S. (1922). A Manual of Indian Timbers. London. Pp.627-628.

[4] Pearson, R.S and Brown,H.P.(1932). Commercial Timber of India.2 Calcutta.pp.894- 902.

[5] IUCN, 2009. Red list of vulnerable species.

[6] Bhat, G.M, Khan,M.A and Mughal,A.H (2007b). Seed maturity indices in Elm (Ulmus wallichiana). A multipurpose tree species of Kashmir valley. Ecol. Env. \& Conservation 13(3): 473-476.

[7] Jaramillo, A. 1981. Review of techniques used to evaluate seedling quality. p. 84-95. In Proc. Intermountain Nurserymen's Assoc. and Western Forest Nursery Assoc. USDA For. Servo Gen. Tech. Rep. INT-I09.

[8] Dumroese,R.K; Mahoney,R.L \& Wenny,D.L 1992. Choosing nursery stock for landscaping, conservation and reforestation. Current Information Series No.923. Univ. of Idaho College f Agriculture.

[9] Mullin, R.E. and C. Christl. 1982. Morphological grading of white pine nursery stock. Forestry Chron. 58:40-44.

[10] Van Den Driessche, R. 1982. Relationship between spacing and nitrogen fertilization of seedlings in the nursery, seedling size, and out planting performance. Can. J. For. Res. $12: 865-875$.

[11] Smith, D.M. 1962. The Practice of Silviculture, 7th ed. John Wiley \& Sons, New York

[12] Shoulders, E. 1961. Effect of nursery bed density on loblolly and slash pine seedlings. J. Forestry 59:576-579. 